\title{
Prosaic Realities of the Work Time Dream ${ }^{1}$
}

\author{
JON HENNING
}

\begin{abstract}
This essay re-examines the story of the arrival of the eight-hour day in New Zealand in the 1840s and provides some insight into three other aspects of our work time history. These aspects are the extent to which workers worked long hours in the nineteenth century, the contest between those who sought shorter hours and those who resisted, and the political progress towards shorter hours that began in the 1890s.
\end{abstract}

Samuel Parnell is widely understood to be the crucial figure in the history of New Zealand's eight-hour working day. Arriving as a carpenter in the newly established Wakefield settlement of Wellington in 1840, Parnell used the shortage of builders to force his potential client to concede the eight-hour day, effectively mounting what he later called "the first strike for eight hours a-day the world has ever seen." 2 Fifty years later, the emerging trade union movement celebrated Parnell as "the father of the eight hours movement," and he has been enshrined as such ever since. ${ }^{3}$

Like other such “origin stories," Parnell's has the advantage of simplicity and brevity, and celebrates the plucky underdog, the brave worker, in ways that appeal to much in New Zealand's preferred self-representation of national character. Other origin stories share the same advantages, like that of Henry Jackson, who arrived in January 1840 "having come to an understanding on the voyage that only eight hours a day should be worked in the new land, the resolve [being] ... put into execution immediately we commenced work." But in his 1923-24 doctoral thesis, labour historian John Salmond urged some caution in accepting this and other stories about the origin of the eight-hour day, generally because they had only come to light from the late 1880s and could not be verified from other sources. He also noted that Jackson had not been aware of Parnell's story before 1890. Even where Salmond had additional sources, however, there is doubt. Salmond's own source for the Jackson story was the Encyclopedia of New Zealand, which in turn implied Jackson's diary as its source. The diary has not survived. Salmond also recounted the eight-hour day origin story for Otago, another Wakefield settlement. In part, Salmond relied on contemporary news reports, though these do not categorically state that the eight-hour day was instituted in Otago in 1848 or 1849. Salmond's further reference to an Australian history which does not cite its primary source does nothing to clarify the matter. ${ }^{4}$

This essay adopts Salmond's caution, and revisits the early history of the eight-hour day in New Zealand. It diminishes the importance of Parnell relative to the impact of the Wakefield colonisation program. It also describes several other possibly deflating realities: the extent to which New Zealanders worked long hours during the nineteenth century; the partisan views and significant opposition to the eight-hour day; and the fact that only in the 1890s did parliament begin to expand beyond the limited statutes of the 1870 s and create a new momentum towards a general eight-hour working day.

Writing in support of Parnell's story, Neill Atkinson has noted that Parnell made a similar claim in the New Zealand Times in 1878 "when many of his alleged rivals were still alive," and none had contradicted him. ${ }^{5}$ In fact, however, there was a dispute. Parnell wrote his letter, already 38 years after the event, to contradict a claim made on behalf of others. Further, inaccurate letters to the editor are not always corrected or contradicted. Parnell was also unsure whether he had established the eight-hour day in "February or March" of 1840. Perhaps a small matter, but another claim followed the next day in the same newspaper from Hanson Terton, a 
neighbour of Parnell's. Terton wrote that from 1844 to 1856 he had employed "much European labour on our mission station at New Plymouth; but I never required more than seven hours a day[,] ... except in harvest time, when the men were paid for overwork." ${ }^{6}$ It is not apparent that the letter was contradicted or modified even though it is inconsistent with the 1841 journal of Henry Weekes which contemporaneously described the loss of the seven-hour day in New Plymouth, yet another Wakefield settlement, after a strike. ${ }^{7}$ Regardless, and despite Salmond's warning, the Parnell story continues to hold centre stage as the basis of the introduction of the eight-hour day into New Zealand. ${ }^{8}$

It is possible that the Parnell story is true. But it is not the whole story nor is it the most important part of the whole story. To make some greater sense of the arrival of the eight-hour day, it is useful to at least briefly consider wider contexts. The concept of the eight-hour day, with its eight hours for each of work, leisure and rest, reputedly originated with the Welshman, Robert Owen, in the early-nineteenth century. Industrial realities meant, however, that the effort to reform work hours in Britain focused on the ten-hour day, in the first instance for women and children. ${ }^{9}$ Rather than Britain, it was in Australasia and in particular the New Zealand Wakefield colonies, that workers were provided with the first opportunity to work the eight-hour day. Regardless of the belated Parnell story, there is in fact contemporary evidence that shows the arrival of the eight-hour day, in sequence, in each of the first three Wakefield settlements. A letter written by Mr Hicks on 4 June 1840, and published in the New Zealand Journal in early 1841, told his brother that he did "not want to return to England to work hard. We work eight hours a day for our two pounds per week.... [I]f you were to know how things were going on you would stop in England but a very little while; for this [Wellington] is an excellent place." 10 The arrival of the seven- and eight-hour day in New Plymouth in 1841 is already noted above. A further letter from George Dodson, written in February 1842 from Nelson, the third Wakefield colony to be established, stated he was "building a house," being paid "£1.1s. per week plus rations" and working "eight hours in the day." 11 Also as above, the Otago settlers arrived with a similar expectation. Moreover, at least some worked an eight-hour day in Canterbury (the last of the Wakefield settlements) in $1850 .{ }^{12}$ Elsewhere, the next reports of the eight-hour day relate to Sydney, Melbourne, and Auckland, but only from the mid-1850s, despite their establishment as colonial settlements in 1788, 1837 and 1840 respectively. ${ }^{13}$

What was special about the Wakefield settlements? In short, Edward Gibbon Wakefield, colonising theorist and prime mover for the establishment of the settlements, gave workers a sense of special licence to negotiate, and the new settlements provided temporarily favourable labour markets. Wakefield worked from premises that capital and labour were oversupplied in Britain and could be much better employed in the colonies if the practice of colonisation was rendered more systematic. Wakefield argued that the traditional practice of selling cheap land allowed ready land ownership for all colonists, leaving few if any to provide labour for industrial scale production, thus jeopardizing the commercial success and ultimate prosperity of the colony. In other words, labourers sent to work for landowners in the colony quickly abandoned their employment to become small subsistence farmers. Even punitive sanctions failed to effectively preserve master and servant relationships when land holding could be obtained cheaply. Wakefield's solution, his scheme of systematic colonisation, was that land should be purchased by a company and resold to wealthy migrants at a relatively high price, and that at least part of the money earned from the sales would pay for the free passage of workers to the new colony. Workers could purchase land but only after a number of years of working as employees and saving. ${ }^{14}$

Based on this theoretical framework, Wakefield promoted and applied in particular the idea that the Wakefield worker colonists travelled as free agents, able to negotiate and obtain their own employment on arrival. The New Zealand Journal underscored this: "At the moment of landing the individual labourer is at liberty to make what bargain he pleases." ${ }^{15}$ Wakefield 
also promised special prosperity: "No pains should be spared to teach the labouring classes to regard the colonies as the land of promise, which it should be their highest ambition to be able to reach." "16 Taken together, he raised considerable, yet undefined, expectations of employment on conditions that would be much better than those in Britain.

There is no direct evidence that the recruiters contracted to get workers onto the emigrant ships to Wellington and the other Wakefield settlements referred to an eight-hour day or other specifically advanced working conditions, but of course Hicks's letter was published in Britain in 1841. Further, the workers' petitions, which came later when the colonists found conditions in the new Wakefield settlements deteriorating, referred back to promises that had encouraged them to immigrate to New Zealand. In New Plymouth, the petition spoke of the guarantee of work and wages that had persuaded them to take the difficult step of leaving their "native land" for New Zealand "with a view of improving our condition and that of our family." 17 Similarly, the Nelson colonists spoke of being "seduced ... into coming to New Zealand" by the promise of work at guaranteed wages and other "flattering pretensions." In describing their ambition, they added that "no man is so happy as the working man for when his day's work [is done], he comes home to his family and by his own fireside he enjoys or should enjoy the fruits of Industry.... [W]e do not want large fortunes of Extraordinary Incomes but to live Comfortably and decently.' ${ }^{18}$ Quite conceivably, comfort and decency included the right to time for leisure. The objects of the Wellington Working Men's Association included the avoidance of the disorder of the Australian colonies, and "raising the hard-working man in the scale of being, and placing him in that situation among the lords of the earth, which as a member of the same family is his natural inheritance." 19

The initial state of the Wakefield settlements also aided the worker colonists. The arrival in small fleets of unattached employers and workers en masse created a dual labour market. There were some, such as builders, who had specialised skills in short supply and were in a strong position to demand advanced conditions. But even the labourers, for whom the settlements were as yet unready, had an advantage. The Wakefield colonising company had a vested interest in projecting an image of success to encourage continued immigration. It could ill afford reports filtering back to Britain of discontented newly arrived colonists without work. It wanted to make money and had to attract colonists to a remote location in competition with closer, better known and established settlements. On this basis, the company almost immediately promised the guaranteed work and wages referred to later by the petitioners in New Plymouth and Nelson. ${ }^{20}$ It seems likely that Dodson was one of those who received guaranteed work. His reference to building his own house provides another reason why workers would have been especially keen to obtain an eight-hour working day, and for employers to rationally concede. Workers also required personal time for the establishment of gardens.

Wakefield's theory and the economic and industrial conditions of the early colonies provide a necessary broader context for understanding the Parnell story and more generally the arrival of the eight-hour day in Wellington and other small New Zealand settlements in the 1840s. The context explains why the eight-hour day initially appeared in these special settlements and not others. Then follow the stories of contenders seeking to be the first, or among the first, to make the most of the favourable circumstances.

The eight-hour day had arrived in New Zealand. But what exactly did that mean for New Zealand workers in practice $?^{21}$ The extent to which the eight-hour day subsequently applied across different workforces can be usefully assessed by reviewing Salmond and a number of official sources. There is an absence of fine detail, especially early on, but this improves from the 1870s. In terms of a starting point, there is a sense of general application in the early Wakefield settlements. Hicks and Weekes indicate that the eight-hour day may have generally applied in Wellington and New Plymouth in 1840 and 1841. For what it is worth, Atkinson's account of the Parnell story, which includes reference to the proselytising or coercion of 
immigrants as they arrived in Wellington, is not inconsistent with these indications. ${ }^{22}$ There is some evidence of subsequent regression from this norm. The New Zealand Company records show that its hours of work increased to nine a day for six days a week in 1843, when the commercial position of the Wellington settlement began to obviously deteriorate. ${ }^{23}$ Wellington labourers in or around 1849 were reported to be working eight hours in the winter and ten in the summer. ${ }^{24}$ Col. Pharazyn, in the Legislative Council, later recalled "that in a very short time" after the establishment of the Wellington settlement "a period of distress arose" as a consequence of which "wages fell" and "the hours of labour were considerably increased." 25

Salmond provides, in addition, various helpful references from the 1850s. Building trades workers in Auckland forced their employers to concede the eight-hour day in $1856 .{ }^{26}$ After, they worked eight hours; before, they had worked longer. Auckland engineers, still seeking the eight-hour day, petitioned for it in $1863 .^{27}$ In promoting his immigration scheme, Vogel, Premier and Colonial Treasurer, claimed in 1875 not only that the eight-hour day had been instituted "from the earliest days of settlement" but that it was also "taken for granted as part of the national way of life." 28 The predominance of the evidence is, however, that a significant (though indeterminate) proportion of the population were working more than eight hours a day in the early 1870s. One of the principal objects of the Auckland Working Men's Protection Society, formed in 1871, continued to be "the encouragement of the eight hours' movement."29 The Otago Daily Times reported in 1872 that "In certain establishments in Dunedin, sewing girls and dressmakers are compelled to work long hours on Saturday, frequently to 10,11 or 12 o'clock at night, an abuse long since remedied in England." ${ }^{30}$ Butchers and bakers in Wellington were reported to have obtained "more wages and shorter hours" in 1873, though generally the working days in these two trades were very long, commonly ten or more hours. ${ }^{31}$ Wellington bootmakers, also in 1873, alleged they were being "asked to work 16 hours a day." 32 The same year, Wellington seamen obtained an agreement whereby they worked 12 hours out of $24 .{ }^{33}$ Parliament passed the Employment of Females Act 1873 to restrict the hours of females and young persons working in factories to eight hours. ${ }^{34}$ The following year, some of the workers at Lyttleton struck for an eight-hour day and the payment of overtime, and subsequently agreed to a nine-hour day with Saturday to finish at 4 p.m. ${ }^{35}$

This pattern also continues after the commencement of the 'long depression' (from the late 1870 s to the 1890s). In 1881, the Otago Trades and Labour Council adopted a political programme that included as an object: "The eight hours' system to be legalised." ${ }^{36}$ The following year, the president of the council stated "that experience had shown that it would be impossible to carry on the Eight Hours' system without an Act of Parliament." 37 The council also expressed the "desirability of encouraging and making compulsory the Eight Hours' system." 38 The first eight hours Bill, in 1882, sought parliament's endorsement that eight hours should be a day's work and 48 hours a week's work. It failed to pass, as did all the subsequent eight hours Bills. ${ }^{39}$ In 1884, in relation to the extensive hours worked by shop workers, the Wellington Trades Council committed to campaign for the early closing of shops at 9 p.m. on Saturday. ${ }^{40}$ This was fully supported by all the trades and labour councils in $1885 .{ }^{41}$ The councils also resolved in 1885 that a measure should be instituted "to compel all employers to have their employees working inside the factories instead of at their homes" in order that "the system known as the sweating system be prevented." They were concerned that some women were working eight hours in the factories and then taking work home, work often requiring many more hours to complete. ${ }^{42}$ A similar concern had been recorded for bootmakers in the $1870 \mathrm{~s} .{ }^{43}$ Salmond describes at length the work from the late 1880 s, led by Rutherford Waddell, a dynamic and forthright Presbyterian minister, to highlight and resolve the problem of sweating in Dunedin, and the subsequent findings of the Sweating Commission. ${ }^{44}$ In 1890, the Eight-Hours Federated Union formed in Wellington to further promote general acceptance of the eight-hour system. ${ }^{45}$ Wellington tramway workers were reported in 1890 to be working an 
average of 80 hours per week. ${ }^{46}$ Some stokers for the Christchurch Gas Company in 1890 were working 84 hours a week. ${ }^{47}$ The Dunedin Building Trades Union stated in one of its rules in 1890 that it sought "To obtain a working day of eight hours at a recognised rate of wages..4 The 1893 platform for the Dunedin Workers' Political Committee included "A statutory eight hours' day for all workers, or 44 hours per week." 49 The extent to which the eight-hour system applied may have declined with the coming of the 'long depression' from 1878, but Salmond's thesis shows only partial coverage even before that date.

The parliamentary debates, principally relating to the eight hours Bills of the 1880s and 1890 s, are valuable sources that confirm the scarcity of eight-hour a day work, and add specific information on the variety of hours being worked by different occupational groups. The details come from both supporters and opponents of the Bills.

Most, on both sides of the argument, agreed that an eight-hour custom existed, but largely as an urban phenomenon. Those to whom the custom applied were referred to as mechanics or artisans (e.g. carpenters, bricklayers, blacksmiths, tailors) and urban labourers, who were paid by the hour. ${ }^{50}$ They worked eight hours a day, six days a week, or arithmetical variants that allowed the Saturday work day to be shortened to a part or half day in accordance with "a very general practice in the whole of the Australian colonies." ${ }^{51}$ Miners also worked, in some places, for eight hours. ${ }^{52}$

In addition to this information, the parliamentarians reported that many other workers worked longer than eight hours, clearly identifying particular groups. Railway engine drivers certainly worked ten hours a day, though there were claims that large numbers also worked twelve to fifteen hours a day. ${ }^{53}$ General engine drivers and bullock drivers worked ten to twelve hours per day. ${ }^{54}$ Factory workers worked variously eight or nine hours a day. ${ }^{55}$ Some took work home and did additional hours. ${ }^{56}$ Workers for millers worked twelve-hour shifts. ${ }^{57}$ Timber mill workers worked ten hours a day. ${ }^{58}$ Boys in the flax mills were also working ten-hour days. ${ }^{59}$

Regarding service and office work, one opponent of the 1882 Bill admitted that domestic servants worked from 6.00 or 6.30 in the morning to 10 at night, and grooms and menservants even longer. ${ }^{60}$ From other reports, clerks were kept "at work to all hours of the night." ${ }^{61}$ Post officials were on duty for ten to twelve hours, though they were said to have a quiet time in the middle of the day. ${ }^{62}$ Shop assistants worked at least nine to ten hours a day, with reports of more extreme hours in the 1889 Shop-hours Bill debate. ${ }^{63}$ Opponents justified the long shop hours on the basis of easy work. ${ }^{64}$ Hotel waiters had "to be up the very first thing in the morning, and they were last in the establishment to go to bed." ${ }^{65}$ Stout, the Premier, sought an amendment to the 1887 Eight Hours Bill to specifically prohibit barmaids from working more than eight hours. ${ }^{66}$

Farm workers also worked from dawn to dusk, or variants such as 7 a.m. to 6 p.m. ${ }^{67}$ Some of the opposing parliamentarians were at pains to downplay the extent of the rural working day by claiming considerable downtime outside peak work periods such as harvest and lambing. ${ }^{68}$ Shearers worked up to fifteen to sixteen hours a day for nine months of the year. ${ }^{69}$ Bush workers worked ten hours a day. ${ }^{70}$ Adding to the picture of a working culture in which long hours were often a fact of life, workers on cooperative schemes not infrequently worked fourteen hours a day. ${ }^{71}$

Two other sources, the 1890 Sweating Commission and the recommendations and awards emerging from the arbitration system from the late 1890s, are worth citing as further evidence of the reality of working hours. Neither source necessarily provides representative accounts or records of workers' hours, but while it is likely the reports to the Sweating Commission tended to be of those most badly treated, the first awards represented some of the best industrial conditions on the basis they were largely achieved by the best organised groups of workers. 
Given the industrial and urban importance of Dunedin in New Zealand in the nineteenth century, the Otago witnesses who appeared before the Sweating Commission covered a relatively wide range of industries and occupations. The commission's chief interests included the conditions under which the tailoresses worked. While unable to agree that sweating existed, the commission acknowledged that some were "engaged for very long hours."72 The Dunedin inspector confirmed that tailoresses had been taking work home to complete after hours, some willingly. ${ }^{73}$ Also interviewed, Silas Spragg, the local journalist involved from the outset in investigating the concerns raised by Waddell, noted the "very low rates of remuneration obtained in many cases, making it necessary that the operatives should work very long hours in order to earn wages upon which they could live." 74 Two of the tailoress witnesses reported working twelve hours and more. ${ }^{75}$ Even so, a general view that the formation of the Tailoresses Union had improved matters emerged from the interviews. Representing the Bakers' Society, James Dickson also told the commission that "The bakers are now employed eight hours a day, and before the society was formed they worked in some cases sixteen hours per day for the same pay that they now get for eight hours." 76 The Bootmakers Union prevented workers taking work home, and kept work time to 48 hours a week. ${ }^{77}$

Further witnesses confirmed long hours for tram workers and sailors. Although contradicting each other on the details of the working week, the tram employer and his workers seemed generally agreed that the working week was at least 55 hours. ${ }^{78} \mathrm{~J}$. A. Millar, Secretary of the Maritime Council, told the commission that sailors worked 14 to 16 hours a day while at sea and eight when in port. He also commented on a number of other occupations and acknowledged that some factories conformed to the "eight-hours system." He noted that other factories, however, started early and finished late. ${ }^{79}$ This was supported by a rope-making factory worker, who stated that he worked ten and three-quarter hours on week days and six and a quarter hours on Saturday. ${ }^{80}$

In some of the other evidence, dairymen were reported as working from 5 a.m. to 8 p.m.; laundry workers, nine and a half hours, six days a week; millers somewhere between 68 and 72 hours a week; and pastry cooks, from 7 a.m. to a finishing time of around 7 to 9 p.m. on weekdays, and either 5 a.m. to 2 p.m. or 7 a.m. to 11 p.m. or midnight on Saturday. ${ }^{81}$ Hairdressers worked daily from eight in the morning to ten at night with a later finish on Saturday of midnight or 1 a.m. on Sunday morning. ${ }^{82}$ "Mr T," a butcher, told the commission that "The long hours is our grievance. I start at 7 in the morning, and my work lasts till 8, and sometime half past 8 , every night. On Friday night it is 9, and on Saturday night 10 or 11 o'clock, before I get away." 83

The first recommendations and decisions arising from the operation of the Industrial Conciliation and Arbitration Act 1894 began to be issued from 1897. To consider a sample of these from the Auckland and Otago/Southland industrial districts for the period 1897 to 1899 , it is evident from the outset that some workers had entrenched the eight-hour day and its optimal concomitant, the 44-hour week of five eight-hour weekdays and half a day's work on Saturday. The privileged group included house painters and other building-trades workers in both districts. ${ }^{84}$ Coal miners worked variously defined eight-hour days, some measured to include any time underground, others only time at the coal face. ${ }^{85}$ Wharf labourers worked an eight-hour day at an hourly rate. ${ }^{86}$ The Dunedin tailoresses working on piece rates worked 45 hours a week (at least at their factories). ${ }^{87} \mathrm{~A}$ conciliation board recommended as a "temporary compromise" for Dunedin linotypists that "day hands" work 45 hours per week and "night hands" 42 hours. ${ }^{88}$ The plumbers were not to exceed 47 . A later award shows they worked a maximum of eight and a half hours on weekdays and four and a half on Saturday. ${ }^{89}$ The union for the Auckland furniture trade workers sought a 44-hour week. The conciliation board recommended 47 hours per week. ${ }^{90}$ Again in Auckland, the award for the bootmakers was 48 hours and the conciliation board recommendation for curriers was that their hours "shall not 
exceed forty-eight per week; the week's work to end at 12 o'clock on Saturday." tailors, moulders, bootmakers, tinsmiths and sheet metal workers worked 48 hours over five weekdays and half a day on Saturday. ${ }^{92}$

There were awards and recommendations, however, that did not provide eight-hour days or similar variations, and tended to confirm the long hours reported to the Sweating Commission. In the case of Auckland bakers, their hours were 54 per week including sponging. ${ }^{93}$ Drivers of carts were required, from Monday to Friday, to leave their stables by 7.30 a.m. and return at 6 p.m. On Saturdays, they left at 7 a.m. and returned by 1.30 p.m. A later award indicates that they may have looked after their horses both before and after. ${ }^{94}$ The union for the Auckland butchers sought a 58-hour week. The conciliation board recommended instead 61/2 hours in summer and 591/2 in winter. ${ }^{95}$ In Dunedin, the records for bakers are somewhat contradictory. A board recommendation in August 1897 confirmed that nine hours would continue until November and hours would then reduce to eight hours. A court award in December of the same year, however, set daily hours at eight and a half. ${ }^{96}$ Recommendations for pastrycooks in 1898 and 1899 set weekly hours at $51 .{ }^{97}$ Seamen watches, during which they had to "perform any work required of them," totalled 12 hours duty a day at sea with some of the time paid at overtime rates. Work hours reduced to eight hours when in port. ${ }^{98}$

While it is clear that some workers worked an eight-hour day in the early Wakefield settlements, we can only really guess as to how common this was. The information improves over time, however. The occupational tables from the 1901 Census show at a highly aggregated level very large numbers of workers in the agricultural and the domestic services sectors. Of all breadwinners, a third worked in agriculture and more than ten per cent worked in domestic occupations. Large numbers also worked in shops, offices and in transport. ${ }^{99}$ All these areas of work were notorious for long hours. On this basis alone, it is relatively clear that an eight-hour system operated but it did not cover most workers, even in the towns. In fact, many appear to have worked very long hours. The recommendations and awards also confirmed two senses of the eight-hour day. Some worked a true eight hours, Monday to Friday, and half a day on Saturday. Others worked up to 48 hours a week (the equivalent of six eight-hour days) but lengthened their weekdays to allow for a shortened Saturday.

In explaining these long hours, it is necessary to make the obvious point that as much as workers may have wanted the eight-hour day and had support from various quarters, there was also and always had been strong opposition in the colony to the shorter working day. Simply in terms of economic interest, employers were generally opposed to providing terms of employment that improved working lives. The initial conditions in the early Wakefield settlements were exceptionally advantageous for the newly arriving workers and allowed them to extract the eight-hour day. Subsequently, however, economic downturns and increased levels of unemployment pressured or allowed employers to push terms such as hours of work in the other direction. This regression has already been noted above with respect to the early Wellington settlement. Similarly, a speaker in the 1882 Eight Hours Bill debate noted the impact of the "long depression": "The eight-hours system, which one part of the colony at all events began, and which worked most beneficially, had been trenched upon very severely of late, and there had been growing indications of a desire on the part of employers still further to break down what was known as the Otago eight-hours system."100

Workers found it difficult to resist. Only a small number belonged to unions. Erik Olssen and Len Richardson note the particular difficulties for organising that existed in New Zealand: the small urban base, scattered factories and workshops, and a rural labour force largely attached to small farms. ${ }^{101}$ The data on hours indicate that some level of trade unionism enabled groups of urban and skilled workers such as building tradesmen to hold on to the eight-hour day. Even so, they felt under threat. Other workers had very much more limited ability to obtain the eight-hour day or fend off attacks on wages and conditions of work. 
Recourse to politics also provided little assistance. As already noted, the Employment of Females Act had been enacted in 1873. It imitated a Victorian (Australia) Bill, was seen as barely relevant at the time, seems have been subject to only the scantest scrutiny before enactment, and was always difficult to enforce despite later amendment. It also constituted the general limit of progress. Subsequently, the Otago Trades and Labour Council stated in 1882 the impossibility of the eight-hour system continuing without statutory assistance. Legislative initiatives followed, particularly in the form of eight-hours Bills, but met with considerable criticism and hostility and were blocked. Tom Brooking, in his biography of Richard Seddon, describes two variants of liberalism in play: classical liberalism, with the emphasis on liberty and laissez-faire policy; and popular liberalism, with a focus on fairness and the use of state power to moderate the impact of laissez-faire policies. ${ }^{102}$ Advocates of the eight-hours Bills, predominantly in the House of Representatives (the lower chamber of the parliament), reflected the popular variant. The determined and effective resistors, particularly the entrenched majority in the Legislative Council (the upper chamber), were very clearly in a well-practised classical camp.

The parliamentarians in favour of the Bills highlighted a number of reasons for supporting and extending the application of the eight-hour day, one set of which was framed in terms of the well-being of workers. They argued that men could not constantly work for more than eight hours and a stop had to be put to the grinding down of men "by long hours of labour." 103 Stout expressed the common view that workers released from hours of work had increased time "to cultivate their minds and raise themselves intellectually." 104 Similarly, others saw the prospect of elevation and assistance in developing social and moral qualities. ${ }^{105}$ Time for families to be together and for wholesome recreation and "natural rest" was important. ${ }^{106}$ English experience showed that shorter hours led to longer and more comfortable lives. ${ }^{107}$ Increased accidents also resulted from the long hours worked by railwaymen. ${ }^{108}$

Other reasons put forward for the eight-hour day related to the development of new technology and unemployment. Labour had an entitlement "to share in the advantages of the machinery now employed," and the only way they could derive a benefit was by a reduction in hours. ${ }^{109}$ Reduced hours of work would "cause a much larger number of persons to be employed." "Workers required regulation in order to stop employers increasing hours of work in times of "surplus labour." 111 The supporters of the Bills also urged parliament to keep up with developments in Britain, Australia and the United States. Essentially, they sought to use pride in social progress, and concern that New Zealand was becoming a laggard, as motivations for legislative action. ${ }^{112}$

The arguments against the Bills focused in particular on economic matters and individual rights. Wages were a major target. Employers and their political allies recognised that workers would want reduced hours without a reduction in pay and were keen to see the expectation blunted. As a counter, they claimed that the introduction of the eight-hour day would likely lead to a shift from daily or weekly wages to hourly rates and to casualization. This had already occurred in the United States, with the effect "that there are a whole lot of unemployed young men wandering about the streets eager to get even a few hours' employment daily in the endeavour to keep body and soul together." 113 They also warned that if more workers were employed because of restricted hours, each worker would receive less pay. ${ }^{114}$ The messages were clear: the eight-hour day might appear attractive but it had in reality serious consequences of reduced income and job insecurity.

Predictably, opposing parliamentarians also argued that it was just simply wrong "to interfere with the law of labour - the law of supply and demand." 115 Leading the response in the Council to the 1892 Eight Hours Bill, Pharazyn stated that workers could secure good wages working eight hours a day, but this "is due to causes over which legislation has practically no control." That is, "the rate of wages and the number of hours men have to work 
is merely a question of the relations between labour and capital." In accordance with "the main propositions laid down by Adam Smith," one either abided by the market or suffered the consequences. ${ }^{116}$

Further economic objections were interspersed through the debates. These included the argument that employers, particularly farmers, could not afford any increase in wage costsindeed "the workman ... is better off than his employer"; the argument that reduced hours at existing daily or weekly rates would inflate the cost of labour above its true value, leading to an inability to employ; the argument that the great investments made in bringing labour to the colony would be partly wasted; and the argument that a restriction on labour would hold back the overall productivity of the colony and reduce its competitiveness against other colonies and countries. $^{117}$

The opponents of regulation also emphasised, time and again, freedom to contract. For example, one noted that "restrictions imposed upon labouring-men would be resented by the men themselves," and another, extravagantly, that legislation would widen the problem of "agitators interfering with the workman as if he were a baby in long clothes who required to be nursed by measures of this kind." 118 It all simply amounted "to interfering with the liberty of the subject." ${ }^{119}$ Further, "legislation of this kind will tend to destroy the independence and selfreliance of the nation". ${ }^{120}$

There were still other objections: eight hours was only applicable to a few groups of workers and not relevant to many others, including farmworkers; many workers were engaged by the month or year (hours of work fluctuated considerably and thus there was a need for give and take); employers required flexibility, especially on farms; skilled work could not be easily shared; work was easier than it used to be; and regulation would increase conflict and unwanted litigation. ${ }^{121}$ A number rejected the Bills as unnecessary on the basis that where the eight-hour day currently applied it was also entrenched and thus already completely safe. ${ }^{122}$

The debates provide little sense that either party was succeeding in substantially persuading the other. Mainly they were at loggerheads, posturing, and talking past each other. On the issue of individual liberty, for example, supporters of the legislation argued that there was no equality in negotiating. In their view, "the freedom of contract in the case of the weak is freedom for the strong to overreach and oppress." 123 The vigorous counterarguments offered by opponents of the legislation included: "of all rights ... the right to property in his own person," was, for men, "amongst the most complete"; it was a "perfectly monstrous interference with a man's liberty to say to him that he shall be punished if he works half an hour longer than the majority choose to think is the proper time for him to work"; and "working-classes" were "just as able to protect themselves as any other class." 124

As already noted, the Bills put forward by the proponents of the eight-hour day were all rejected. While the House at times supported the Bills, the Council, which the opponents dominated, adamantly rejected them, and exercised vetoes by rendering progress in the parliament untenable, especially at its committee stages, or by directly voting the legislation down.

This eventually changed, however, and effective legislation began to appear from the mid-1890s. Much of the change revolved around the emergence of the Liberals. The evidence to the Sweating Commission included examples of unions exercising influence in controlling and decreasing hours of work. This recently acquired confidence and success, associated with union activity overseas and especially the London dock strike, was short-lived, collapsing with the defeat of the major unions in the Maritime Strike in September 1890. A few months later, however, the general election resulted in a new Liberal Party taking control of the House. Michael King notes "the shocked response" to the commission's report as a factor in the result. ${ }^{125}$ Len Richardson connects the defeat in the Maritime Strike with a heightened labour awareness that assisted the Liberals. ${ }^{126}$ Brooking refers to "the introduction of universal 
manhood suffrage and labour's increased organisation," but without attributing the latter to the Maritime Strike. ${ }^{127}$ As can be the case in elections, it is difficult to be clear on what exactly had determined the outcome. Regardless, the victory resulted in the introduction of "a liberal and reformist agenda," which included labour legislation incorporating provisions to reduce working hours. ${ }^{28}$

The Liberals' first raft of these labour Bills, from 1891 to 1893, were substantially reduced or blocked by the Council. This reflected the first unproductive stages for the Liberals of a larger battle of wills over appointments to the Council and their attempt to moderate the chamber. Resolution took time, but, after re-election in 1893, the Liberals had more success, including the enactment of the Industrial Conciliation and Arbitration Act 1894, which became among other things the main instrument for the progressive reduction of the working day.

The origins and much of the early history of the statute are comprehensively described and explained by Jim Holt, including the intentions of Reeves, the Minister of Labour and author of the legislation. Holt notes that, while there was an intention that the statute should stop the development of major industrial action, it was much less clear that Reeves intended that it should lead to the regulation of conditions of employment. Nonetheless, as the arbitration system developed, this is generally what happened. ${ }^{129}$ Under the Act, registered unions were able, with minimal membership, to force employers into bargaining. Further, if settlements could not be reasonably reached, the unions were able to apply for arbitration and thereby obtain adjudicated and binding terms and conditions of employment. As it progressively advanced conditions of work in general, the system also enabled the incremental reduction in the length of the working day. This followed from an increase in the unionisation of workers, encouraged by the advantage of assisted bargaining, and the ongoing pressure in such bargaining for the periodic improvement of hours of work in successive agreements and awards. In effect, the legislation produced, over time, initially unintended but ultimately important and positive consequences for the extension of the eight-hour working day.

The other main related legislative advances made by the Liberals by the beginning of the twentieth century were the Coal Mines Act 1901 and the Factories Act 1901. In between the Industrial Conciliation and Arbitration Act and these later statutes, Reeves left for London in early 1896 to become New Zealand's Agent-General, and Seddon, the Premier, replaced Reeves as the Minister of Labour. Holt notes that Seddon faced a new political constraint as he managed the increasing influence of country members within the Liberal Party, and John Martin adds that Seddon called a halt to labour legislation to enable public opinion to catch up with developments. ${ }^{130}$ Despite this, Seddon continued to be lobbied to introduce new legislation including a further eight hours Bill and, perhaps because it was an election year, he relented and introduced an eight hours Bill in $1896 .{ }^{131}$

The 1896 Bill differed from previous Bills in two specific respects. It proposed a narrow occupational coverage, and also a tight restriction on overtime which, if worked, would be paid at double time. Seddon sought to cover only local authority workers, miners and factory workers. He argued that he was confirming existing practice and, in the case of gold miners, also clearing up some confusion in the courts. ${ }^{132} \mathrm{He}$ expected difficulty in obtaining acceptance of the overtime provision but nevertheless hoped "by stopping overtime" to "find employment for others." 133 The Bill passed the House but failed in the Council. The narrower focus on a few groups of workers provided a guide to what Seddon would do in 1901. The overtime restrictions, on the other hand, were substantially relaxed in the later instance. ${ }^{134}$

Understandably, the failure of the 1896 Bill did not satisfy those seeking change, and Seddon remained under pressure. This included various reports during the second half of the 1890s from Tregear, his Secretary of Labour, that strongly indicated the need for legislation to protect the hours of adult male workers in shops, offices and factories in the same way that adult female workers were protected (even though Tregear also recognised that the 
enforcement of the restrictions on women's and young persons' hours remained problematic). Tregear added that the relevant unions were not strong enough, and that any workers who sought to take a lead in representing matters through the arbitration system would be intimidated. ${ }^{135}$ George Russell (Member of the House of Representatives [MHR] for Riccarton) applied additional pressure at the beginning of the 1901 session by introducing his own eight hours Bill, on the basis that Seddon had failed to bring in a government version. In explaining the Bill, Russell noted that the arbitration system had been making progress but there were a great number of cases to consider. He added that he wanted to aid the non-unionised, and that it was a Bill of broad principle. His prompts included letters received that gave the "most deplorable accounts of the hours men have to work in connection with the dairying industry in the North Island" that put them in danger of becoming "little better than white slaves."136 Seddon agreed with the Bill but predicted it would fail for all the reasons that had dogged the previous eight hours Bills. He acknowledged that the arbitration system and factories legislation could only do so much for some workers. ${ }^{137}$ And of course the Bill did fail to pass.

Russell's reprimand was in fact unfair and Seddon already had other legislation under preparation. This included the Factories Bill, which reportedly had been extensively rewritten by the labour representatives within the Liberal Party and had created "much excitement and agitation." 138 In what looks like a piece of tactical bargaining, the earlier relatively benign draft had been altered to include provisions which impacted on overtime and the handling of perishable goods, alterations that were seen as attacks on the interests of employers and farmers. Those representing the views of the latter groups in the House condemned the changes as the work and influence of the trade unions. The Labour Bills Committee subsequently went to work to mend the differences and ultimately produced a face-saving compromise for the parties and, with little further work required, the House of Representatives passed the Bill. Possibly deceived but patronising nonetheless, Bollard (MHR for Eden) said that the labour members "deserved credit for having modified their views when they came to rub shoulders with members on this side of the House." 139 The Council also passed the Bill and completed its parliamentary passage. As enacted, the statute provided a 48 -hour week and an eight and three-quarter hour day for adult male workers (with some exceptions). The standard week and day for female and young male factory workers had been revised and set at 45 and eight and one-quarter hours. The provisions were subject to awards under the arbitration system. Seddon disagreed with Tregear, as had the majority on the Labour Bills Committee, that men and women should have the same standard hours. ${ }^{140}$

Enthusiastic claims followed: the Bill set a "provision for an eight-hours day ... in our statute law"; it gave "effect to the long-delayed demand that there should be an eight-hours day statutory law in this colony"; and "this Government stands first in the legislative history of the world." 141 Seddon concluded that "At all events, we have here fixed the forty-eight hours a week, or eight hours a day, and in that I think we are in advance of any other Legislature, except as applied to mines." "142 The remarks were a little slippery, because the Act did not refer to an eight-hour day, and even for women and young persons, the daily hours had increased to eight and a quarter. It was, nonetheless, the entrenchment of the Australasian custom which traditionally had modified weekday hours to allow for the Saturday half holiday. ${ }^{143}$

The extraordinary four and a half hour third reading of the Bill in the House, normally pro forma and requiring no debate, demonstrated that passage had been secured by Seddon's skilled political management and not through the conversion of the opposition. In leading the response to the only relatively shorter Council third reading and resigned to the enactment, McLean wondered "whether our industries are in such a flourishing condition at the present moment that they can afford to stand up against the legislation with which we [the parliament] are harassing them every year." In response to the restricted hours, employers would need to ensure they got value for money: they needed to "exact labour from our men in proportion to 
the amount we pay."144 Jennings reminded the Council that the wages of pieceworkers would reduce, and predicted that the Australian woollen mills, which worked longer hours, would take "our trade." 145

In the same session, parliament also passed the Coal Mines Act, which provided miners with the eight-hour day from bank to bank, conditional, like the Factories Act, on the provisions in current awards under the Industrial Conciliation and Arbitration Act. In this case, there were no significant House or Council debates. ${ }^{146}$ Parliament's Labour Bills Committee also considered a further Bill, the Shops and Offices Bill, and a revised draft was debated by the Council, reversing the normal order of debate because of insufficient time on the House's legislative schedule. Jenkinson noted "the most drastic proposal" of the Bill was the attempt to limit hours for adult male workers to fifty-two a week, with the additional provision for three hours overtime a day for no more than 30 days a year. He and others strongly disagreed with the Bill; it made no progress, and it was discharged at the end of the session. ${ }^{147}$

The Factories and the Coal Mines Acts represented a significant step forward. They complemented the Industrial Conciliation and Arbitration Act, and for the first time provisions that regulated the hours of adult male workers had been included in legislation. Yet the eighthour day or the 48-hour week still only applied to some parts of the workforce. Much more remained to be done. Another essay is required to cover further developments in the twentieth century.

The primary purpose of this essay has been to provide a realistic sense of the struggle for the eight-hour day in nineteenth-century New Zealand. Clearly, the Wakefield settlements led the way in the establishment of the eight-hour day. And there were special reasons for this which did not depend on Parnell. It is equally evident that the extent of the initial success did not last. When economic conditions faltered, many employers were able to either erode or deny their workers the eight-hour day. Their supporters in parliament were also able to hold up any political redress for a substantial period. Essentially, the incidence of the eight-hour day in New Zealand went backwards, and the effective recovery of some momentum towards shorter working days did not begin to occur until the 1890s.

This essay also challenges the nation's annual celebration of the eight-hour day with its reference and focus on the Parnell story. Fundamentally, the object is to celebrate labour and the necessary strength of unions in a strongly contested industrial environment. The familiar ring of the arguments of the 1880s and 1890s reflects the considerable sense in which this contest continues unabated. The Parnell story has the virtue of being short and pithy. But it is also the story of what we would call today a self-employed contractor independently setting his terms. This revisionist essay puts at the centre of the eight-hour day story the reality of aspiration and a tough collective struggle with many agents contributing - the Otago Trades and Labour Council, Bradshaw (MHR for Waikaia and Dunedin Central, and a major force behind the earlier Bills), Waddell, Reeves, and Seddon spring to mind, but only as the most prominent. The argument is, at its simplest, that Parnell should exit left and the celebration should be centred on the perseverance of the many.

As a final note, the essay also demonstrates perhaps yet again the early awareness of some of our unionists of the need to access political power, and also how reluctant or slow the polity can be to provide necessary assistance. 
${ }^{1}$ This essay could not have been written but for the presence of mind of Taneroa Paratene. The author thanks
Jen Wilson, Rosemary Mercer and Marcus Henning for their invaluable assistance. For a much more detailed earlier draft of the essay, see "The Struggle for the Eight-hour Day in Nineteenth Century New Zealand" (Hocken Library).

${ }^{2}$ N. Atkinson, "Samuel Parnell," Ministry for Culture and Heritage, updated 2 November 2015, www.nzhistory.net.nz/people/samuel-parnell

${ }^{3}$ Ibid.

${ }^{4}$ J. D. Salmond, "The History of the New Zealand Labour Movement" (PhD Thesis, New Zealand, 1923-24, revised 1928, 18ff., Hocken Library. Salmond's Australian source was W. E. Murphy, The History of the Eight Hours Movement (Melbourne: Spectator, 1896), 20.

${ }^{5}$ Atkinson, "Samuel Parnell."

${ }^{6}$ New Zealand Times, 21 and 22 February 1878.

${ }^{7}$ J. Rutherford and W. Skinner, ed., The Establishment of the New Plymouth Settlement (New Plymouth: Avery, 1969), 53, 86, 95. The New Plymouth workers initially worked a seven-hour day, and went on strike for higher wages. When the strike was defeated, they had to accept as a condition of their return to work an eight-hour day. ${ }^{8}$ For example, J. Belich, Paradise Reforged: A History of the New Zealanders from the 1880s to the Year 2000 (Auckland: Penguin, 2001), 133.

${ }^{9}$ D. Thompson, The Chartists: Popular Politics in the Industrial Revolution (London: Breviary, 1984), 24-25; D. G. Wright, Popular Radicalism: The Working-Class Experience 1780-1880 (London: Longmans, 1988), 101ff; W. R. Cornish and G.de N. Clark, Law and Society in England 1750-1950 (London: Sweet and Maxwell, 1989), 302; H. Roth, Trade Unions in New Zealand Past and Present (Wellington: Reed, 1973), 3.

${ }^{10}$ New Zealand Journal, 15 January 1841.

${ }^{11}$ Letters from Settlers and Labouring Emigrants in the New Zealand Company's Settlements of Wellington, Nelson, and New Plymouth, from February, 1842, to January, 1843 (London: Smith, Elder, 1843), 65-66.

${ }^{12}$ J. R. Godley (ed.), Letters from Early New Zealand by Charlotte Godley 1850-1853 (Christchurch: Whitcombe and Tombs, 1951), 138.

${ }^{13}$ B. Ford and D. Plowman, Australian Unions: An Industrial Relations Perspective (Melbourne: Macmillan, 1983), 31; Salmond, "The History of the New Zealand Labour Movement," 27.

${ }^{14}$ J. Henning, "New Zealand: An Antipodean Exception," New Zealand Journal of History 41, no. 1 (2007): 69ff.

${ }^{15}$ New Zealand Journal, 2 January 1841.

${ }^{16}$ M. F. Lloyd Pritchard, ed., The Collected Works of Edward Gibbon Wakefield (Auckland: Collins, 1969), 99100. Marx also recognised that Wakefield had "discovered" something new to say about relations between labour and capital: K. Marx, Capital, vol. 1 (London: Penguin, 1976), 932f.

${ }^{17}$ Petition to Wickstead, 14 May 1842, N.Z.C.308/1.

${ }^{18}$ Nelson Examiner, 21 January 1843.

${ }^{19}$ New Zealand Journal, 19 June 1841.

${ }^{20}$ J. Henning, "A Rejection of Bondage" (MA Thesis, University of Otago, Dunedin, 2004), 150ff.

${ }^{21}$ Among the many matters that may be of interest but cannot be covered in this essay is a comparison of working hours in different countries and colonies. To refer very briefly to the experience in Britain, legislation in 1847 tended to normalise the 10-hour day, union pressure for the nine-hour day began in the 1850s with relatively widespread success by the 1870s, and activity increased for the eight-hour day from the mid-1880s. See P. Blyton, Changes in Working Time: An International Review (London: Croom Helm, 1985), 17-21.

${ }^{22}$ Atkinson, "Samuel Parnell."

${ }^{23}$ William Wakefield to Secretary, New Zealand Company, 8 March 1843, C.O. 208/101.

${ }^{24}$ Otago News, 24 January 1849.

${ }^{25}$ NZPD, vol. 77 (1892), 234-35.

${ }^{26}$ Salmond, "The History of the New Zealand Labour Movement," 27.

${ }^{27}$ Ibid, 30 .

${ }^{28}$ Ibid, 29.

${ }^{29}$ Ibid, 30.

${ }^{30}$ Ibid, 282.

${ }^{31}$ Ibid, 67 and $367-71$.

${ }^{32}$ Ibid, 87.

${ }^{33}$ Ibid, 88.

${ }^{34}$ Ibid, $283-85$.

${ }^{35}$ Ibid, 87-88.

${ }^{36} \mathrm{Ibid}, 236$.

${ }^{37}$ Ibid, 233. 
${ }^{38} \mathrm{Ibid}, 136$.

${ }^{39}$ Ibid, 33-34.

${ }^{40} \mathrm{Ibid}, 165$.

${ }^{41}$ Ibid, 187-88.

${ }^{42}$ Ibid, 189, 205-06.

${ }^{43}$ Ibid, 87.

${ }^{44}$ Ibid, 206-30.

${ }^{45}$ Ibid, 31 .

${ }^{46}$ Ibid, 170-71.

${ }^{47}$ Ibid, 153 .

${ }^{48}$ Ibid, 30 .

${ }^{49}$ Ibid, 494-97.

${ }^{50}$ NZPD, vol. 52 (1885), 196.

${ }^{51}$ Ibid: vol. 51 (1885), 597-99.

${ }^{52}$ Ibid: vol. 55 (1886), 557.

${ }^{53}$ Ibid, vol. 41 (1882), 171.

${ }^{54}$ Ibid, vol. 64 (1889), 222.

${ }^{55}$ Ibid: vol. 57 (1887), 346-47.

${ }^{56}$ AJHR, H-2 (1878), 13.

${ }^{57}$ NZPD, vol. 96 (1896), 107.

${ }^{58}$ Ibid, vol. 57 (1887), 347.

${ }^{59}$ Ibid, vol. 75 (1892), 450.

${ }^{60}$ Ibid, vol. 42 (1882), 381.

${ }^{61}$ Ibid, vol. 41 (1882), 175.

${ }^{62}$ Ibid, vol. 64 (1889), 223.

${ }^{63} \mathrm{Ibid}$, vol. 64 (1889), 221, 494-95.

${ }^{64}$ Ibid: vol. 74 (1891), 194.

${ }^{65} \mathrm{Ibid}$, vol. 42 (1882), 381.

${ }^{66}$ Ibid, vol. 57 (1887), 343.

${ }^{67}$ Ibid, vol. 49 (1884), 23.

${ }^{68}$ Ibid, vol. 75 (1892), 452-53.

${ }^{69}$ Ibid, vol. 52 (1885), 197.

${ }^{70}$ Ibid, vol. 64 (1889), 225.

${ }^{71}$ Ibid, vol. 96 (1896), 102.

${ }^{72}$ AJHR, H-5 (1890), iii-iv, vi.

${ }^{73}$ Ibid, 1.

${ }^{74}$ Ibid, 4.

${ }^{75}$ Ibid, 6.

${ }^{76}$ Ibid, 33-34.

${ }^{77}$ Ibid, 15.

${ }^{78}$ Ibid, 17, 19-20.

${ }^{79} \mathrm{Ibid}, 11-13$.

${ }^{80}$ Ibid, 24.

${ }^{81}$ Ibid, 17, 26-27.

${ }^{82}$ Ibid, 18.

${ }^{83}$ Ibid, 23.

${ }^{84}$ Department of Labour, Awards, vol. 1 (1901), 9, 17, 41, 350, 410, 444.

${ }^{85}$ Ibid, 46, 52, 355, 446.

${ }^{86}$ Ibid, 409.

${ }^{87}$ Ibid, 399.

${ }^{88}$ Ibid, 384.

${ }^{89}$ Ibid: 11; vol. 6 (1906), 94.

${ }^{90}$ Ibid, vol. 1 (1901), 24-25.

${ }^{91}$ Ibid, 28, 49.

${ }^{92}$ Ibid, 325, 356, 372, 424.

${ }^{93}$ Ibid, 7. Sponging: yeast starter preparation.

${ }^{94}$ Ibid, 13; vol. 3 (1903), 79.

${ }^{95}$ Ibid, vol. 1 (1901), 47-48.

${ }^{96}$ Ibid, 320, 323-24.

${ }^{97}$ Ibid, 347-48, 352-53.

Journal of New Zealand Studies NS25 (2017), 57-71 
98 ibid, pp.415-16.
${ }^{99}$ Results of a Census of the Colony of New Zealand Taken for the Night of 31 st March 1901 (Wellington:

Government Printer, 1902), 301 and 304-05.

${ }^{100}$ NZPD, vol. 41 (1882), 177.

${ }^{101}$ In E. Fry (ed.), Common Cause: Essays in Australian and New Zealand Labour History (Wellington: Port Nicholson Press, 1986), 1-2.

102 T. Brooking, Richard Seddon: King of God's Own (Auckland: Penguin, 2014), 23.

${ }^{103}$ NZPD, vol. 49 (1884), 21, 28-29.

${ }^{104}$ Ibid, 22.

105 Ibid, vol. 41 (1882), 173.

106 ibid: vol. 79 (1893), 121.

107 Ibid, vol. 49 (1884), 25.

${ }^{108}$ Ibid, 28.

${ }^{109}$ Ibid, vol. 55 (1886), 560; vol. 49 (1884), 24.

${ }^{110}$ Ibid, vol. 96 (1896), 264.

111 Ibid, vol. 49 (1884), 30.

112 Ibid, vol. 68 (1890), 78

${ }^{113}$ Ibid, vol. 81 (1893), 644.

${ }^{114}$ Ibid, vol. 64 (1889), 223.

115 Ibid, vol. 52 (1885), 199.

${ }^{116}$ Ibid, vol. 77 (1892), 233-38.

${ }^{117}$ Ibid: vol. 49 (1884), 27; vol. 52 (1885), 201; vol. 42 (1882), 382; vol. 73 (1891), 319-20; vol. 96 (1896), 267.

${ }^{118}$ Ibid, vol. 42 (1882), 381; vol. 52 (1885), 199.

${ }^{119}$ Ibid, vol. 57 (1887), 344.

${ }^{120}$ Ibid, vol. 52 (1885), 198

${ }^{121}$ Ibid: vol. 42 (1882), 381; vol. 49 (1884), 27, 29, 32; vol. 52 (1885), 196; vol. 96 (1896), 103.

122 Ibid: vol. 55 (1886), 559; vol. 74 (1891), 116-17; vol. 75 (1892), 448

${ }^{123}$ Ibid, vol. 75 (1892), 445.

${ }^{124}$ Ibid, vol. 96 (1896), 267.

${ }^{125}$ M. King, The Penguin History of New Zealand (Auckland: Penguin, 2012), 237.

${ }^{126}$ L. Richardson, "Parties and Political Change," in W. H. Oliver, ed., The Oxford History of New Zealand (Auckland: Oxford, 1981), 197.

${ }^{127}$ Brooking, Richard Seddon, 86.

${ }^{128}$ Richardson, "Parties and Political Change," 200.

${ }^{129}$ J. Holt, Compulsory Arbitration in New Zealand: The First Forty Years (Auckland: Auckland University Press, 1986), 33ff.

${ }^{130}$ Ibid, 25; J. E. Martin, Holding the Balance: A History of New Zealand's Department of Labour, $1891-1995$

(Christchurch: Canterbury University Press, 1996), 61.

${ }^{131}$ NZPD, vol. 96 (1896), 102-04, 114, 116.

${ }^{132}$ Ibid, 100.

${ }^{133}$ Ibid, 114-15.

${ }^{134}$ Factories Act 1901, S.22.

135 AJHR, H-6 (1897), iii-v; H-11 (1899), ii-iii, x; H-11 (1900), ii; H-11 (1901), ii-iii, vi.

${ }^{136}$ NZPD, vol. 116 (1901), 303-04.

137 Ibid, 305-07.

${ }^{138}$ NZPD, vol. 119 (1901), p.365.

${ }^{139}$ Ibid, vol. 116 (9101), 306; vol. 119 (1901), 331ff, 362ff.

${ }^{140}$ Ibid, 331-32, 334.

141 Ibid, 337, 377.

142 Ibid, 388.

${ }^{143}$ Factories Act 1901, S.31(1)-(2).

${ }^{144}$ NZPD, vol. 119 (1901), 1005.

${ }^{145}$ Ibid, 1010.

146 Ibid, 1151-52.

${ }^{147}$ Ibid, vol. 117 (1901), 367ff; vol. 119 (1901), 1169. 